\title{
Decadal Analysis of Efficient Cropping Zone for Cotton Crop in Tamil Nadu, India
}

\author{
Rajashree Khatua*, S. Panneerselvam, V. Geethalakshmi, M. Kumar and P. Jeyakumar
}

TNAU, Coimbatore-641003, India

*Corresponding author

\section{A B S T R A C T}

\section{Keywords}

Efficient cropping zone, Most efficient cropping zone, Less efficient cropping zone, Inefficient cropping zone, Relative spread index and Relative yield index

\section{Article Info}

Accepted:

22 June 2020

Available Online:

10 July 2020
Tamil Nadu traditionally grows cotton in an area of about $0.2 \mathrm{~m}$ hectares and produces about 0.6 million bales of cotton and because of its climate and soil, the State is ideally suited for producing long and extra long staple cottons. This analysis was carried out to identify the efficient cropping zones of Cotton crop in Tamil Nadu state. An analytical study was done to identify the Efficient cropping zones of the Cotton crop of Tamil Nadu were keyed out with 10 years data (20042015) using Relative Yield Index (RYI) and Relative Spread Index (RSI). We were able to find out the efficient zone for cotton crop. A study was conducted at Agro Climate Research Centre, Tamil Nadu Agricultural University, Coimbatore during 2018-19 to delineate ECZ for the cotton crop of Tamil Nadu. It was found that Salem and Ariyalur both come under more efficient cropping zones for cotton crop. Most of the parts of Tamil Nadu come under NECZ and LECZ. Four districts of Tamil Nadu are coming under efficient cropping zone and they have more area compared to yield. Those districts are Tiruchirapalli, Perambalur, Madurai and Virudhanager.

\section{Introduction}

Cotton, the 'White Gold' enjoys a premier position amongst all commercial crops in India. In the raw material consumption basket of the Indian textile industry, the proportion of cotton is around 59\%. In India, cotton productivity is very low as compared to other countries. More than 50 percent of the cotton area is covered by cotton hybrids and the hybrids contribute about 60 per cent to national production (Santhy et al., 2008).
Conversely, about 60 per cent of cotton in India is cultivated under rain-fed conditions and this is regarded as one of the reasons for the low productivity recorded in the country. Cotton is very important to the Indian economy because it provides gainful employment for millions of people as well as source of foreign exchange for the country. Cotton is grown in nine major states in three different zones. Punjab, Haryana and Rajasthan in north zone. Maharashtra, Gujarat and Madhya Pradesh in central zone and 
Andhra Pradesh, Karnataka and Tamil Nadu in the south zone are the major cotton growing states in India. Tamil Nadu is the tenth largest cotton-producing state in India with a production of 5 Lakh Bales. Tamil Nadu accounts for more than $6 \%$ in the total cotton production in the country and cotton is grown in 70,000 hectares of land in the state. Tamil Nadu is the state in India with the highest cotton yield, which is 1,214 kilograms per hectare. Coimbatore, Vallalur, Madurai, Ramanathapuram, Salem, and Tiruchirapalli are some of the major cotton producing districts in Tamil Nadu.

One such method for identifying the potential area of crops is by calculating Relative Yield Index and Relative Spread Index and in turn Efficient Cropping Zone of the crops (Veeraputhiran, 2003).

In this context, a study was conducted at Agro Climate Research Centre, Tamil Nadu Agricultural University, Coimbatore during 2018-19 to delineate ECZ for the cotton crop of Tamil Nadu.

\section{Materials and Methods}

Data collection: Efficient cropping zone for cotton was studied for all the districts of Tamilnadu. Hence the time series data available at district level, from 2005-2015 (10 years) regarding the area, production and productivity of cotton crop were collected from the directorate of economics and statistics, Government of Tamil Nadu, Chennai.

\section{Method adopted}

The formula propagated by Kanwar (1972) was used to find out Relative Spread Index (RSI) and Relative Yield Index (RYI) for each crop to identify efficient crop zone for the selected crops in Tamil Nadu. The details are given here under.

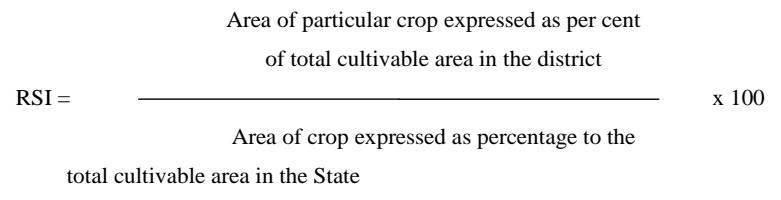

Where in RSI: Relative Spread Index

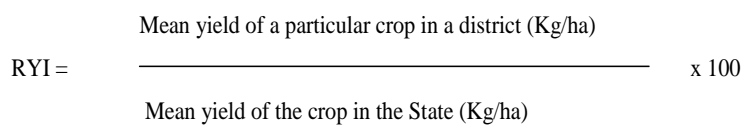

Where in RYI: Relative Yield Index

The criteria suggested by Kanwar (1972) were used to demark efficient cropping zone as per RSI \& RYI values obtained from computation in respect of rice, maize, sorghum, pearl millet, black gram, green gram, groundnut and gingelly.

\section{Results and Discussion}

For cotton crop, Salem and Ariyalur district was found to be MECZ, mainly because it has black cotton soil and also has more number of textile industries in Tamil Nadu. The MECZ considering as High RSI and RYI for cotton fell with Salem (194.1/120.7) and Ariyalur (247.1/1310).

The reason accredited for superior RSI and RYI values in these districts for the marketing facility which is highly pronounced in these areas. Farmers are showing larger interest in cotton because of normal monsoon, increase in minimum support price and better realization compared to other crops. The districts Tiruchirapalli, Perambalur, Madurai and Virudhunagar come under ECZ with low RSI and High RYI. Though the yield potential good, the spread is low and hence efforts should be made mainly to increase the area of the crop. 
Table.1 Criteria for Efficient Cropping Zone

\begin{tabular}{|c|c|l|}
\hline RSI & RYI & \multicolumn{1}{c|}{ Cropping Zone } \\
\hline$>\mathbf{1 0 0}$ (High) & $>100$ (High) & $\begin{array}{l}\text { Most Efficient Cropping Zone (MECZ). The zone with good spread and } \\
\text { more yield of crop. Sustainability options have to identified and imposed. }\end{array}$ \\
\hline$<\mathbf{1 0 0}$ (Low) & $>100$ (High) & $\begin{array}{l}\text { Efficient Cropping Zone (ECZ). The zone with good spread and low yield. } \\
\text { The constraints in area spread have to be identified. The ECZ is renamed } \\
\text { as Yield Efficient Cropping Zone(YECZ) in Agro Climate Research } \\
\text { Centre's Crop Scientist unpublished Report, 2018. }\end{array}$ \\
\hline$>\mathbf{1 0 0}$ (High) & $<100$ (Low) & $\begin{array}{l}\text { Less Efficient Cropping Zone (LECZ).The zone with high spread and Low } \\
\text { yield. The constraints in yield have to be identified. }\end{array}$ \\
\hline$<\mathbf{1 0 0}$ (Low) & $<\mathbf{1 0 0}$ (Low) & $\begin{array}{l}\text { Not Efficient Cropping Zone (NECZ). The zone with low spread and low } \\
\text { yield. Suitability of alternate crops may be assesed. Table }\end{array}$ \\
\hline
\end{tabular}

Table.2 District wise efficient cropping zone in Tamil Nadu

Most efficient cropping zone (MECZ)

\begin{tabular}{|l|c|c|c|}
\hline \multicolumn{1}{|c|}{ DISTRICT } & RSI & RYI & RESULT \\
\hline SALEM & 194.1034 & 120.7003 & MECZ \\
\hline ARIYALUR & 247.943 & 131.0523 & MECZ \\
\hline
\end{tabular}

Efficient cropping zone (ecz)

\begin{tabular}{|l|c|c|c|}
\hline \multicolumn{1}{|c|}{ DISTRICT } & RSI & RYI & RESULT \\
\hline TIRUCHIRAPALLI & 208.6844 & 88.99416 & ECZ \\
\hline PERAMBALUR & 306.2525 & 94.62981 & ECZ \\
\hline MADURAI & 167.6664 & 71.86026 & ECZ \\
\hline VIRUDHUNAGAR & 245.9479 & 79.39764 & ECZ \\
\hline
\end{tabular}

Not efficient cropping zone (NECZ).

\begin{tabular}{|l|c|r|c|}
\hline \multicolumn{1}{|c|}{ DISTRICT } & \multicolumn{1}{c|}{ RSI } & \multicolumn{1}{c|}{ RYI } & RESULT \\
\hline KANCHEEPURAM & 0 & 92.3116 & NECZ \\
\hline THIRUVALLUR & 0.025411 & 25.52511 & NECZ \\
\hline CUDDALLORE & 65.30319 & 80.87384 & NECZ \\
\hline VELLORE & 96.53228 & 97.91377 & NECZ \\
\hline KRISHNAGIRI & 31.63498 & 86.81461 & NECZ \\
\hline THIRUVARUR & 35.75876 & 94.61206 & NECZ \\
\hline RAMANATHAPURAM & 31.69282 & 55.52609 & NECZ \\
\hline SIVAGANGAI & 10.53466 & 96.28847 & NECZ \\
\hline THOOTHUKUDI & 80.12285 & 85.0434 & NECZ \\
\hline THE NILGIRIS & 0.17301 & 99.89114 & NECZ \\
\hline KANNIYAKUMARI & 0.139495 & 27.67305 & NECZ \\
\hline
\end{tabular}


Less efficient cropping zone (LECZ)

\begin{tabular}{|l|c|r|c|}
\hline \multicolumn{1}{|c|}{ DISTRICT } & RSI & RYI & RESULT \\
\hline VILLUPURAM & 58.44739 & 100.3695 & LECZ \\
\hline THIRUVANNAMALAI & 10.04873 & 114.1523 & LECZ \\
\hline NAMAKKAL & 46.67407 & 136.5436 & LECZ \\
\hline DHARMAPURI & 76.55343 & 114.2186 & LECZ \\
\hline COIMBATORE & 22.28349 & 100.0914 & LECZ \\
\hline THIRUPPUR & 6.511407 & 143.3371 & LECZ \\
\hline ERODE & 19.16124 & 147.4378 & LECZ \\
\hline KARUR & 3.495141 & 111.6305 & LECZ \\
\hline PUDUKKOTTAI & 0.962279 & 108.963 & LECZ \\
\hline THANJAVUR & 15.25804 & 133.7913 & LECZ \\
\hline NAGAPATINAM & 22.85143 & 109.8633 & LECZ \\
\hline THENI & 47.35302 & 155.6096 & LECZ \\
\hline DINDIGUL & 26.67133 & 127.0233 & LECZ \\
\hline THIRUNELVELI & 63.28053 & 111.2945 & LECZ \\
\hline
\end{tabular}

Fig.1 Efficient cropping zone for cotton (2005-2015)

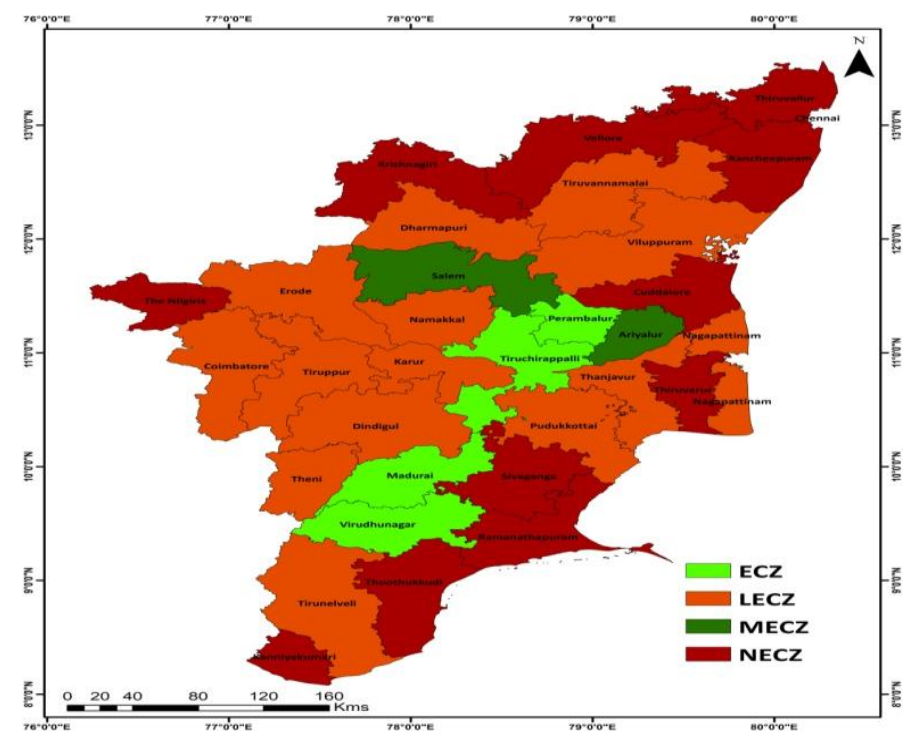

Eleven districts come under NECZ with both low RSI and RYI. Under LECZ most of the districts comes because for low Area and high yield like Villupuram, Thiruvannamalai, Namakkal, Dharmapuri, Thiruppur, Coimbatore, Erode, Pudukkottai, Thanjavur, Nagapatinam, Theni, Dindigul and Thirunelveli. In order to bring ECZ areas under MECZ for the cotton crop, improved cultivars, advanced cultural practices, better management practices and availability of need based quality inputs at reasonable price must be tried. In order to popularize the crop in the NECZ, farmers need to be trained in innovative technologies to explore higher productivity, which can be done by strengthening the extension services. 
In conclusion enhancing and maintaining sustainability in crop productivity is possible only through identification of efficient locations for crops. The crop adaptability to a particular region governs the productivity of the particular crop. At present, there are two methods to identify suitable cropping zones. The identified MECZ and ECZ of cotton crop could be focused for further improvement for surmounting the demand - supply gap and changes in cost structure in cotton production. The districts that fall under high rainfall and hilly zones i.e. Kanyakumari and Nilgiris as well as Ramanathapuram which is a coastal region were found to be inefficient zone for cotton crop and alternate crops must be promoted in those districts.

Some micro level constraints like seed, soil, timely sowing, varietal multiplicity, spacing and plant density, plant protection and IPM adoption are the main cause for less production of cotton in Tamil Nadu. Considering these factors, we need to focus on new technology and crop insurance promoted for efficient cropping zone for cotton crop. Considering these factors, the crop insurance promoted for efficient crop zone would protect the farmers from crop losses.

\section{Abbreviations}

MECZ:- Most Efficient Cropping Zone, ECZ:- Efficient Cropping Zone, LECZ:- Less Efficient Cropping Zone, NECZ:- Not Efficient Cropping Zone, RYI:- Relative Yield Index, RSI:- Relative Spread Index, IPM:- Integrated Pest Management

\section{References}

Kokilavani, S., \& Geethalakshmi, V. (2013). Identification of efficient cropping zone for rice, maize and groundnut in Tamil Nadu. Indian Journal of Science and Technology, 6(10), 5298-5301

Sanbagavalli S, Rohini A et al. (2002). Efficient cropping zones - decadal analysis for major crops in Tamil Nadu, Indian Journal of Agricultural Research, vol 36(4), 227-233.

Thavaprakaash N, Babu C et al. (2008). Identifying potential cropping zones for important horticultural crops of Tamil Nadu, The Madras Agricultural Journal, vol 95(7-12), 418-424.

Veeraputhiran R, Kathikeyan R et al. (2003). Crop planning climate atlas principles, Relative spread index and relative yield index, A.E. Publications, Coimbatore, 156-158.

\section{How to cite this article:}

Rajashree Khatua, S. Panneerselvam, V. Geethalakshmi, M. Kumar and Jeyakumar, P. 2020. Decadal Analysis of Efficient Cropping Zone for Cotton Crop in Tamil Nadu, India. Int.J.Curr.Microbiol.App.Sci. 9(07): 3840-3844. doi: https://doi.org/10.20546/ijcmas.2020.907.449 